\title{
Nano-Phytotechnological Remediation of Endosulfan Using Zero Valent Iron Nanoparticles
}

\author{
Harikumar Puthenveedu Sadasivan Pillai ${ }^{*}$, Jesitha Kottekottil ${ }^{2}$ \\ ${ }^{1}$ Centre for Water Resources Development and Management, Kozhikode, India \\ ${ }^{2}$ Sree Sankara College, Kalady, Ernakulam, India \\ Email: *drpshari@yahoo.co.in
}

Received 14 March 2016; accepted 19 April 2016; published 22 April 2016

Copyright (C) 2016 by authors and Scientific Research Publishing Inc.

This work is licensed under the Creative Commons Attribution International License (CC BY). http://creativecommons.org/licenses/by/4.0/

(c) (i) Open Access

\begin{abstract}
Endosulfan, an organochlorine pesticide, is known for its toxicity and ability to accumulate in the environment. In India endosulfan was banned only in 2011 and hence toxic residues are still persistent in the environment. The abilities of three plant species Chittaratha (Alpinia calcarata), Tulsi (Ocimum sanctum), and Lemongrass (Cymbopogon citratus) to remove endosulfan from soil in the absence and presence of zerovalent iron nanoparticles (nZVIs) $(1000 \mathrm{mg} / \mathrm{Kg}$ of soil), i.e., by phytoremediation and nano-phytoremediation, were determined. Extracted soil samples from the experimental plot were analyzed using Gas Chromatograph with Electron Capture Detector (GCECD) and final dehalogenated product was confirmed by Mass Spectrometer (MS). A. calcarata had the best efficiency compared to the other two plant species and the efficiency decreased in the order $A$. calcarata $>O$. sanctum $>C$. citrates. The initial endosulfan removal rate was high $(82 \%$ was removed within 7 days) when nano phytoremediation experiments were conducted with $A$. calcarata but then gradually decreased, probably because the activity of nZVI decreased over time. The nZVI endosulfan degradation mechanism appears to involve hydrogenolysis and sequential dehalogenation which was confirmed by GC-MS analysis. Only small amounts of endosulfan were accumulated in the plants because the added nZVIs might have promoted the reductive dechlorination of endosulfan.
\end{abstract}

\section{Keywords}

Endosulfan, Phytoremediation, Nano-Phytoremediation, Zerovalent Iron Nanoparticles

\footnotetext{
"Corresponding author.
} 


\section{Introduction}

Nano-remediation studies have shown that Ag, Au, Mg, and Fe nanoparticles can cause several types of halocarbon to be dehalogenated, so it is expected that these types of nanoparticles can also dehalogenate halocarbon pesticides [1]. Nanomaterials can either react directly with a pollutant or support the transformation of the pollutant into less toxic forms [2]. Zerovalent iron nanoparticles (nZVIs) are very reactive because of their small sizes, and they can be used in in situ treatments [3]-[5].

Phytoremediation is a cost-effective "green" technique that has been used to remediate environmental media contaminated with crude oil, explosives, metals, pesticides, solvents, and other pollutants. Certain plants called hyperaccumulators (plants which absorb large amounts of pollutants) are planted at a site based on the type of pollutant present and other site conditions. Plants can act as hyperaccumulators and they can remove pollutants or convert pollutants into harmless products by bioaccumulating, degrading, extracting, or immobilizing the pollutants. Phytoremediation offers advantages over traditional remediation methods such as chemical oxidation, excavation, and thermal treatments [6] [7].

A potential application of a combined usage of nano- and phytoremediation could be the remediation of endosulfan-contaminated soils. Endosulfan is a cyclodiene insecticide and acaricide that becomes adsorbed to soil particles and is persistent in the environment [8]-[10]. The US Environmental Protection Agency has estimated that endosulfan and its metabolites have half-lives between 9 months and 6 years [11]. Endosulfan was found to persist for 1.5 - 2 years in sediment and soil samples in selected areas in eleven Panchayats of Kasaragod District, India [12]. Since the residues of endosulfan can remain in sediment, soil, vegetation etc. for 1.5 - 2 years it is essential that endosulfan should be quickly and effectively removed from affected environment. Nanophytoremediation technique could degrade pollutants such as endosulfan effectively without much impact on environment. In most cases, nanomaterials will not be of human health or ecological concern and may have positive impacts [13]. But not enough information exists to assess environmental exposure for most engineered nanomaterials [14]. A recent study has reported that increased dissolved hydrogen and $\mathrm{Fe}^{2+}$ formed during the process provide evidence for nZVI emplacement and also create favorable environments for microbes to aid long-term bioremediation. In the remediation experiments involving nZVI particles, organic amendments are added during the synthesis or injection to facilitate transport and this can provide carbon and energy for microbial metabolism, thereby enhancing microbial activities which may lead to enhanced rate of degradation of contaminants [15].

The aim of the study described here was to evaluate the possibility of nano-phytoremediating soil contaminated with endosulfan using selected plant species Chittaratha (Alpinia calcarata), Tulsi (Ocimum sanctum), and Lemongrass (Cymbopogon citratus) and nZVIs. nZVIs (1000 mg/kg of soil) were added in to the soil artificially spiked with endosulfan (1139.84 $\pm 0.93 \mu \mathrm{g} / \mathrm{kg})$ and after definite time period (7, 14, 21 and 28 days), $10 \mathrm{~g}$ of soil sample was collected and analysed to find out the concentration of endosulfan in the soil. Plant species were also analyzed to find out the hyper accumulated concentration of endosulfan. The removal efficiencies achieved over $120 \mathrm{~d}$ were determined for soils containing endosulfan and selected plants with and without the presence of nZVIs.

\section{Materials and Methods}

Analytical grade chemicals were used throughout the study. External pesticide reference standards from Merck (Germany) were used.

Easily harvested plants were selected based on their abilities to tolerate or accumulate contaminants, grow quickly, effectively accumulate large quantities of pollutants, and produce large biomass. The plants that were screened were Aerva lanata, Ageratum conyzoides, A. calcarata, Biophytum sensitivum, Cleome viscosa, C. citratus, O. sanctum, Phyllanthus amarus, Plumbago indica, Ruta chalepensis, and Vernonia cinerea. The plants were collected from Kottuli wetland area in Calicut, India. The details of collected plants were identified using the standard literature [16]. All the plants were transplanted into the soils artificially spiked with $1200 \mu \mathrm{g} / \mathrm{Kg}$ of endosulfan and three plants A. calcarata, O. sanctum, C. citrates which grew well were selected for the main experiment.

In the phytoremediation experiments, seedlings (2 weeks old) of the fresh plant species not previously exposed to endosulfan selected after screening were transplanted into rectangular growth chambers containing soil contaminated with endosulfan $(1139.84 \pm 0.93 \mu \mathrm{g} / \mathrm{kg})$. The chambers were placed in a greenhouse that was kept at $30^{\circ} \mathrm{C}$ during the day and $27^{\circ} \mathrm{C}$ at night. Water was added to the soil in each chamber every day to maintain 
appropriate moisture content. The greenhouse study was performed with natural light. The study was continued after the screening period using three plant species that grew well in the endosulfan-contaminated soil. Healthy plants, with similar heights and biomasses, of the selected species were transplanted into rectangular pots for the main study. Three experiments were run separately for each treatment. Samples of the soil and plant material were removed for analysis at regular intervals over 2 months.

nZVIs was synthesized by the reductive precipitation process, reacting $\mathrm{FeCl}_{3}(0.045 \mathrm{M})$ with sodium borohydride (0.25 M) [17] [18]. The vacuum filtration technique was used to separate the black iron nanoparticles from the liquid phase. The solid particles were washed with three $25 \mathrm{~mL}$ aliquots of absolute ethanol. The synthesized nanoparticles were finally dried overnight in an oven at $323 \mathrm{~K}$. A thin layer of ethanol was added to allow the iron nanoparticles to be stored by preventing them from being oxidized [13] [19].

The sizes and shapes of the nano- and submicron-particles were determined using a SU-6600 field emission SEM instrument equipped with a Horiba EDX analyzer (Hitachi High-Technologies, Tokyo, Japan). The size distribution of the nZVIs was further examined using a H07600 transmission electron microscope (Hitachi High-Technologies).

The efficiency at which the nZVIs to be used in the nano-phytoremediation study degraded endosulfan was determined by passing an endosulfan solution (water sample artificially spiked with $105.19 \pm 0.83 \mu \mathrm{g} / \mathrm{L}$ endosulfan) through a column packed with nZVIs. Aliquots of the eluate were collected at regular intervals and the difference between the endosulfan concentrations in the original solution and the eluate were determined. After the column test, the nZVIs from the column were analyzed by scanning electron microscopy (SEM) energy-dispersive X-ray spectroscopy (EDS).

A $4 \mathrm{~kg}$ aliquot of soil spiked with $1139.84 \pm 0.93 \mu \mathrm{g} / \mathrm{kg}$ of endosulfan was added to each pot, and the selected plants were transplanted into the pots. A study was carried out to determine the optimum dosage of nZVIs required to get maximum removal efficiency of endosulfan. The optimum dosage was found to be $1000 \mathrm{mg} / \mathrm{Kg}$. The same amount of nZVIs (1000 mg/Kg) was applied to the soil in each pot. A $40 \mathrm{~mL}$ aliquot of the surfactant Tween 80 was added to each pot to increase the mobilities of the nZVIs [4]. A soil sample (10 g) was collected from each pot after $0,7,14,21$, and $28 \mathrm{~d}$ and analyzed for endosulfan. The sample extracts were analyzed by gas chromatography with electron capture detection (GC-ECD). Two sets of control experiments were performed, one without any treatment and one with only nZVIs added.

Pesticide residues in water samples were extracted using a liquid-liquid extraction method. Pesticide residues in soil samples were extracted using a mixture of chromatographic grade n-hexane and acetone [20]-[22]. Pesticide residues in plant samples were extracted with ethyl acetate, using a procedure that has been described previously [21].

The extracts were cleaned and concentrated, then analyzed using a Varian CP-3800 gas chromatograph with a ${ }^{63} \mathrm{Ni}$ electron capture detector. Separation was achieved using a wall-coated fused silica capillary column $30 \mathrm{~m}$ long, with a $0.32 \mathrm{~mm}$ internal diameter and a film $0.25 \mu \mathrm{m}$ thick. After processing the samples through the different extraction steps, the final concentrated and cleaned up sample was analyzed using Gas Chromatograph using Electron Capture Detector which is specific and highly sensitive for halogenated compounds. A Varian make CP-3800 Gas Chromatograph equipped with $\mathrm{Ni}^{63}$ ECD electron capture detector was used to analyze the pesticides. One microlitre volume of each extract was injected into the injection port using the micro syringe.

WCOT fused silica capillary column of length $30 \mathrm{~m}, 0.32 \mathrm{~mm}$ internal diameter, $0.25 \mu \mathrm{m}$ film thickness was fitted and standard temperature programs were used. Nitrogen (99.999\% purity) was used as the carrier gas and the gas inlet pressure was $80 \mathrm{psi}$ corresponding to a flow rate of $2 \mathrm{ml} \cdot \mathrm{min}^{-1}$. The temperature for injector and detector were $250^{\circ} \mathrm{C}$ and $300^{\circ} \mathrm{C}$, respectively. The temperature column was programmed from 130 (hold 1 min) to $200^{\circ} \mathrm{C}$ at $5^{\circ} \mathrm{C}$ (hold $10 \mathrm{~min}$ ) and then from $200^{\circ} \mathrm{C}$ to $232^{\circ} \mathrm{C}$ at $1^{\circ} \mathrm{C} \mathrm{min}{ }^{-1}$. The chromatograms were recorded and integrated using Star Workstation software. The pesticides detected were compared with that of the standards [21].

Accuracy within-day and between-day precision were assessed using QC samples at three concentration levels of 50, 100 and $200 \mu \mathrm{g} / \mathrm{L}$. The samples were all run in triplicate $(\mathrm{n}=3)$ on three different days and the RSD and relative error (RE) were calculated for each. Acceptable precision here was considered to be an RSD of $<5 \%$. The overall accuracy was assessed by subtracting the theoretical concentration of each QC sample from the mean concentration determined from the three days of analyses. Detection (LOD) and quantitation (LOQ) limits were calculated relative to the values for the blank at the retention times of the analytes (10 injections) [21].

The final degradation product was confirmed by Thermo Trace 1300 Gas Chromatograph with Mass Spectro- 
meter (GC-MS). Data obtained were analysed by two factor ANOVA (Analysis of Variance) technique for comparison of means between days and between treatments.

The impact of nZVIs to the microbes in the soil was also assessed. The bacterial colonies in the control soil (without any nano zero valent iron particles) and soil with added nano particles was assessed by plate count method. The soil samples were serially diluted and number of bacterial colonies formed was counted by plating out the sample of culture on a nutrient agar surface.

\section{Results and Discussion}

A fast and substantial degradation of endosulfan was observed during the column experiment to study the effectiveness of nZVI for the remediation of endosulfan. The column experiment indicated that endosulfan can be treated effectively by using iron nanoparticles at a residence time of less than 40 minutes.

The results of the systematic characterization of the nZVIs by SEM-EDS and transmission electron microscopy are shown in Figures 1-3.

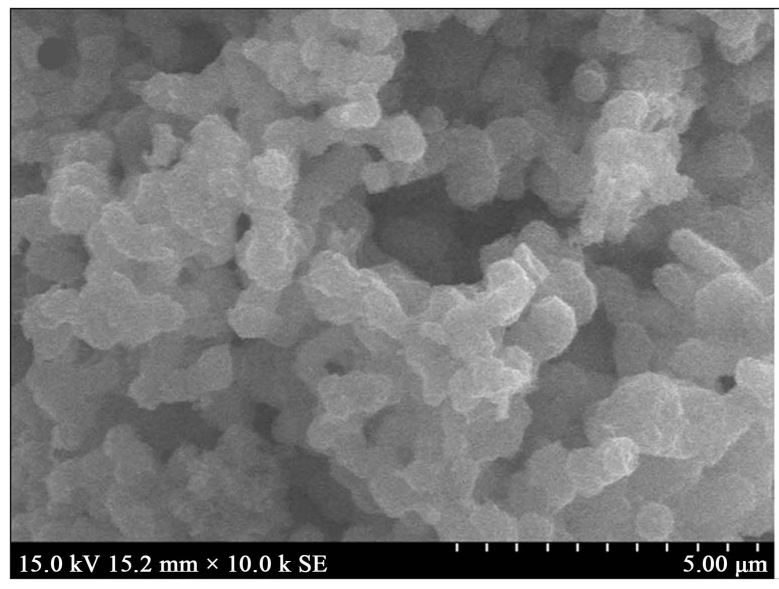

(a)

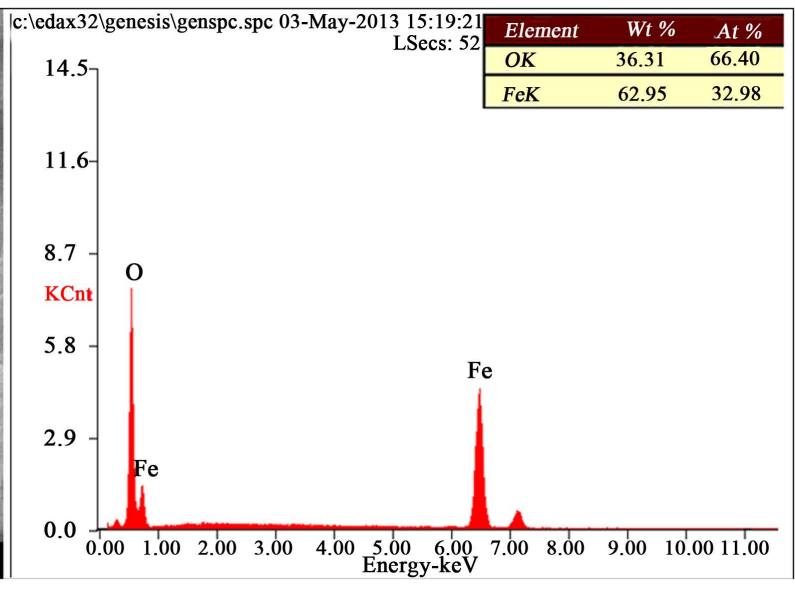

(b)

Figure 1. SEM image (magnification 10.0 k) (a) and energy dispersive X-ray spectroscopy image; (b) of the zerovalent iron nanoparticles.

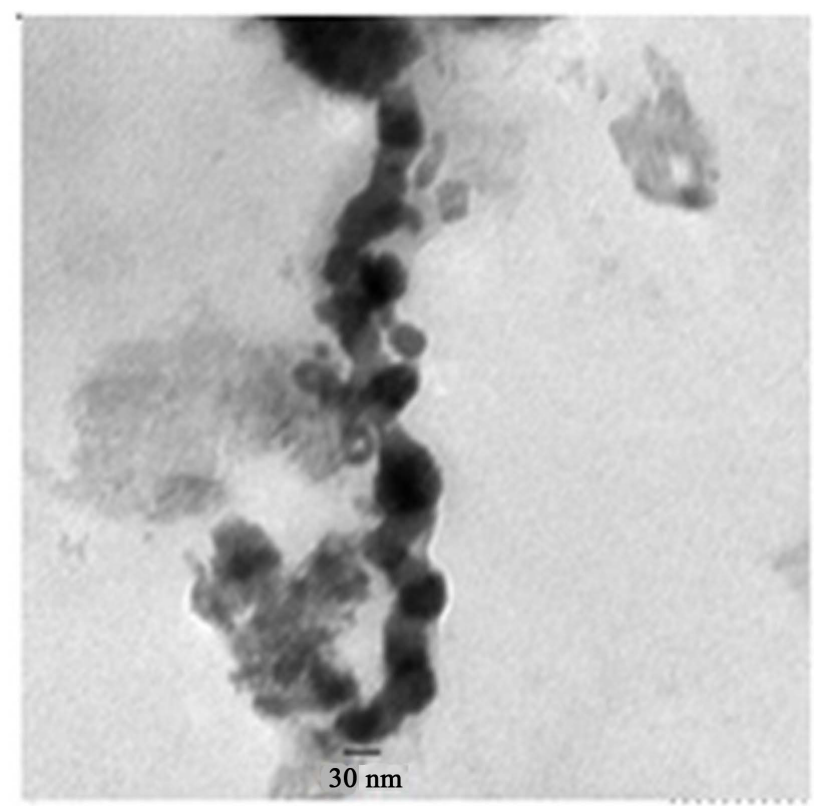

Figure 2. Transmission electron microscopy image (magnification 30.0k) of the zerovalent iron nanoparticles. 


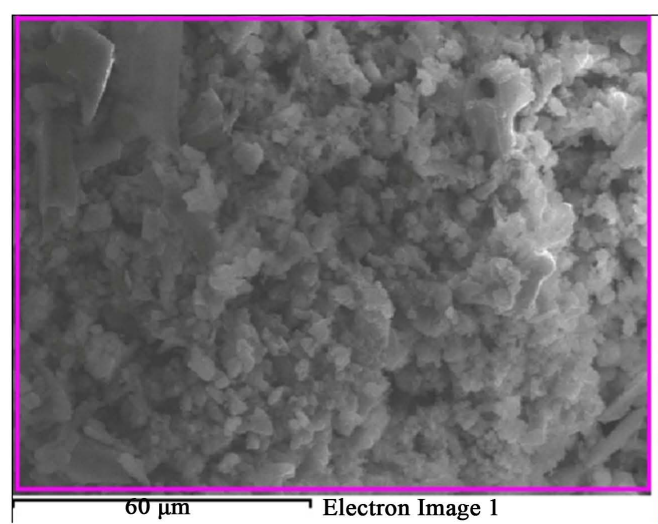

(a)

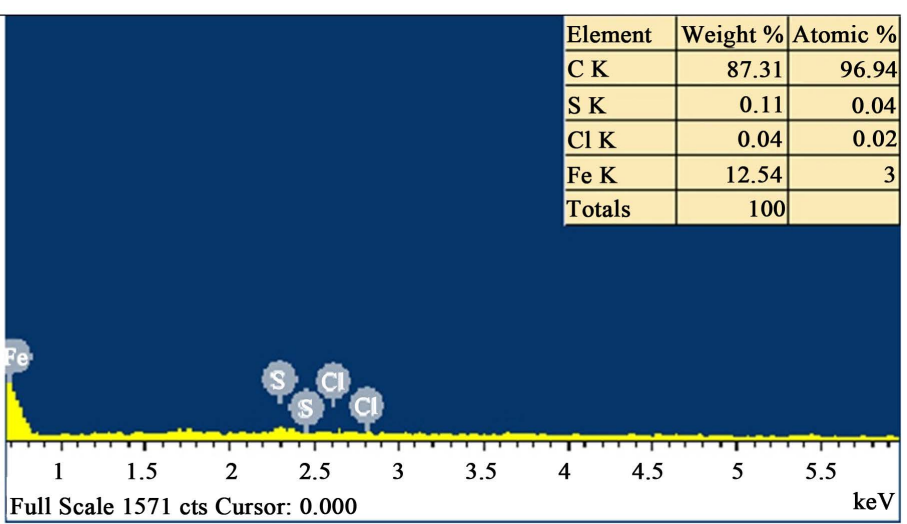

(b)

Figure 3. SEM image (magnification $1.10 \mathrm{k}$ ) (a) and energy dispersive X-ray spectroscopy image; (b) of the zerovalent iron nanoparticles after they had been in contact with endosulfan.

The SEM and TEM images (Figure 1 and Figure 2) of the nZVIs showed that the nZVIs formed were nano spheres that were in contact with each other and formed chains. The linear chains would have formed because of the magnetic properties of iron. The EDS spectra showed that each nZVI had a core of zerovalent iron and a shell mainly composed of iron oxide (FeO). The dual properties of such nZVIs may allow them to be used to separate and transform many different contaminants like trinitrotoluene, chlorinated solvents and pesticides [23] [24]. TEM image (Figure 2) showed that a single particle was typically around $30 \mathrm{~nm}$ in diameter, and most of the particles were less than $100 \mathrm{~nm}$ in diameter. A SEM image of nZVIs after they had been in contact with endosulfan in the column experiment is shown in figure 3. Elements other than iron (e.g., sulfur and chlorine) were detected in the spectral data due to the release of those elements during the degradation of endosulfan by nZVIs.

The results of the phytoremediation, nano-phytoremediation, and control (no treatments) experiments are shown in Table 1.

The results of phytoremediation (Table 1 ) indicated that, A. calcarata was the most effective hyper-accumulator of endosulfan of the species that were tested, removing $81.20 \% \pm 0.20 \%$ of the endosulfan initially added to the soil within $28 \mathrm{~d}$. Endosulfan was removed quickly in the first $7 \mathrm{~d}$ of the experiment, then removed slowly in the following $7 \mathrm{~d}$. C. citratus was also a good remediator, removing $65.08 \% \pm 0.13 \%$ of the endosulfan from the soil within $28 \mathrm{~d}$, although the plants became withered and unhealthy in the final days of the experiment. Of the selected plants, $O$. sanctum was the poorest remediator, removing only $20.76 \% \pm 0.15 \%$ of the endosulfan in the soil within $28 \mathrm{~d}$.

All the plants used in the experiment were analyzed for endosulfan. The A. calcarata plants (which removed $81.20 \%$ of the endosulfan in the soil within $28 \mathrm{~d}$, as stated above) accumulated, in root, shoot and leaves, $80 \%$ of the endosulfan removed from the soil, showing that this species is a good hyper accumulator of endosulfan. The C. citratus and $O$. sanctum plants accumulated $62.18 \%$ and $14.06 \%$, respectively, of the endosulfan they removed from the soil.

The results indicated that nano-phytoremediation is a more effective method for remediating endosulfancontaminated soil than is phytoremediation alone (which is a long-term process). Only limited studies have reported on the application of combined effects of nano remediation and phytoremediation. Nano-phytoremediation study for the removal of Trinitrotoluene (TNT) from contaminated soil has been reported [24]. Removal efficiency was found to be highest when nano-phytoremediation experiments were conducted in soil with the TNT/nZVI ratio of 1/10 with the complete TNT remediation (initial TNT concentration: $100 \mathrm{mg} / \mathrm{kg}$ ) within 60 days.

The proportions of the endosulfan in the spiked soil removed from the control experiments (without any treatment) and in the phytoremediation and nano-phytoremediation experiments using A. calcarata, C. citratus, and $O$. sanctum are shown in Figure 4. The endosulfan was removed efficiently in the first $7 \mathrm{~d}$ of the nanophytoremediation experiments and the concentration reached below detection limit within $28 \mathrm{~d}$ when $\mathrm{A}$. calcarata was used and nZVIs were added to the soil. In case of nano-phytoremediation experiments with $C$. citrates and $O$. sanctum, $86.16 \% \pm 0.09 \%$ and $76.28 \% \pm 0.19 \%$ of endosulfan was removed respectively within a period of 28 days. 
Table 1. Endosulfan concentration (mean value) in the soil and the proportion of the endosulfan in the soil that was removed in each phytoremediation and nano-phytoremediation experiment. Mean of three experiments and standard deviation.

\begin{tabular}{|c|c|c|c|}
\hline Treatment & Days & $\begin{array}{c}\text { Total endosulfan } \\
(\alpha+\beta \text {-endosulfan }) \\
\text { concentration }(\mu \mathrm{g} / \mathrm{kg})\end{array}$ & $\begin{array}{l}\text { Proportion of endosulfan } \\
\text { removed (\%) }\end{array}$ \\
\hline \multirow{5}{*}{ Control (without any treatment) } & 0 & $1139.84 \pm 0.93$ & 0 \\
\hline & 7 & $1053.14 \pm 1.35$ & $7.61 \pm 0.12$ \\
\hline & 14 & $1010.95 \pm 1.68$ & $11.31 \pm 0.15$ \\
\hline & 21 & $926.03 \pm 5.31$ & $18.76 \pm 0.47$ \\
\hline & 28 & $910.42 \pm 3.77$ & $20.13 \pm 0.33$ \\
\hline \multirow{5}{*}{ Control (with added nZVI) } & 0 & $1139.84 \pm 0.93$ & 0 \\
\hline & 7 & $942.71 \pm 1.75$ & $17.29 \pm 0.15$ \\
\hline & 14 & $905.93 \pm 3.32$ & $20.52 \pm 0.29$ \\
\hline & 21 & $627.10 \pm 1.13$ & $44.98 \pm 0.10$ \\
\hline & 28 & $511.87 \pm 1.55$ & $55.09 \pm 0.14$ \\
\hline \multirow{5}{*}{$\begin{array}{l}\text { Alpinia calcarata } \\
\text { (phytoremediation) }\end{array}$} & 0 & $1139.84 \pm 0.93$ & 0 \\
\hline & 7 & $550.10 \pm 1.52$ & $51.74 \pm 0.13$ \\
\hline & 14 & $501.05 \pm 0.32$ & $56.04 \pm 0.03$ \\
\hline & 21 & $232.14 \pm 0.43$ & $79.63 \pm 0.04$ \\
\hline & 28 & $214.33 \pm 2.23$ & $81.20 \pm 0.20$ \\
\hline \multirow{5}{*}{$\begin{array}{c}\text { Alpinia calcarata } \\
\text { (nano-phytoremediation) }\end{array}$} & 0 & $1139.84 \pm 0.93$ & 0 \\
\hline & 7 & $202.64 \pm 1.65$ & $82.20 \pm 0.14$ \\
\hline & 14 & $83.59 \pm 1.09$ & $92.67 \pm 0.10$ \\
\hline & 21 & $57.94 \pm 0.96$ & $94.92 \pm 0.08$ \\
\hline & 28 & BDL & $\approx 100$ \\
\hline \multirow{5}{*}{$\begin{array}{l}\text { Ocimum sanctum } \\
\text { (phytoremediation) }\end{array}$} & 0 & $1139.84 \pm 0.93$ & 0 \\
\hline & 7 & $1045.80 \pm 2.01$ & $8.25 \pm 0.18$ \\
\hline & 14 & $932.74 \pm 1.57$ & $18.17 \pm 0.14$ \\
\hline & 21 & $920.42 \pm 2.33$ & $19.25 \pm 0.20$ \\
\hline & 28 & $903.19 \pm 1.70$ & $20.76 \pm 0.15$ \\
\hline \multirow{5}{*}{$\begin{array}{c}\text { Ocimum sanctum } \\
\text { (nano-phytoremediation) }\end{array}$} & 0 & $1139.84 \pm 0.93$ & 0 \\
\hline & 7 & $1015.50 \pm 2.02$ & $10.91 \pm 0.18$ \\
\hline & 14 & $732.25 \pm 1.07$ & $35.76 \pm 0.09$ \\
\hline & 21 & $366.65 \pm 1.17$ & $67.83 \pm 0.10$ \\
\hline & 28 & $270.42 \pm 2.16$ & $76.28 \pm 0.19$ \\
\hline \multirow{5}{*}{$\begin{array}{l}\text { Cymbopogon citratus } \\
\text { (phytoremediation) }\end{array}$} & 0 & $1139.84 \pm 0.93$ & 0 \\
\hline & 7 & $1085.06 \pm 1.05$ & $4.81 \pm 0.09$ \\
\hline & 14 & $456.05 \pm 0.86$ & $59.99 \pm 0.12$ \\
\hline & 21 & $433.13 \pm 1.26$ & $62.0 \pm 0.08$ \\
\hline & 28 & $398.09 \pm 1.51$ & $65.08 \pm 0.13$ \\
\hline \multirow{5}{*}{$\begin{array}{l}\text { Cymbopogon citratus } \\
\text { (nano-phytoremediation) }\end{array}$} & 0 & $1139.84 \pm 0.93$ & 0 \\
\hline & 7 & $427.11 \pm 0.76$ & $62.53 \pm 0.07$ \\
\hline & 14 & $213.80 \pm 1.02$ & $81.24 \pm 0.09$ \\
\hline & 21 & $183.63 \pm 0.99$ & $83.89 \pm 0.09$ \\
\hline & 28 & $157.73 \pm 1.07$ & $86.16 \pm 0.09$ \\
\hline
\end{tabular}

BDL: Below detection limit; Detection limit: $0.05 \mu \mathrm{g} / \mathrm{kg}$. . 


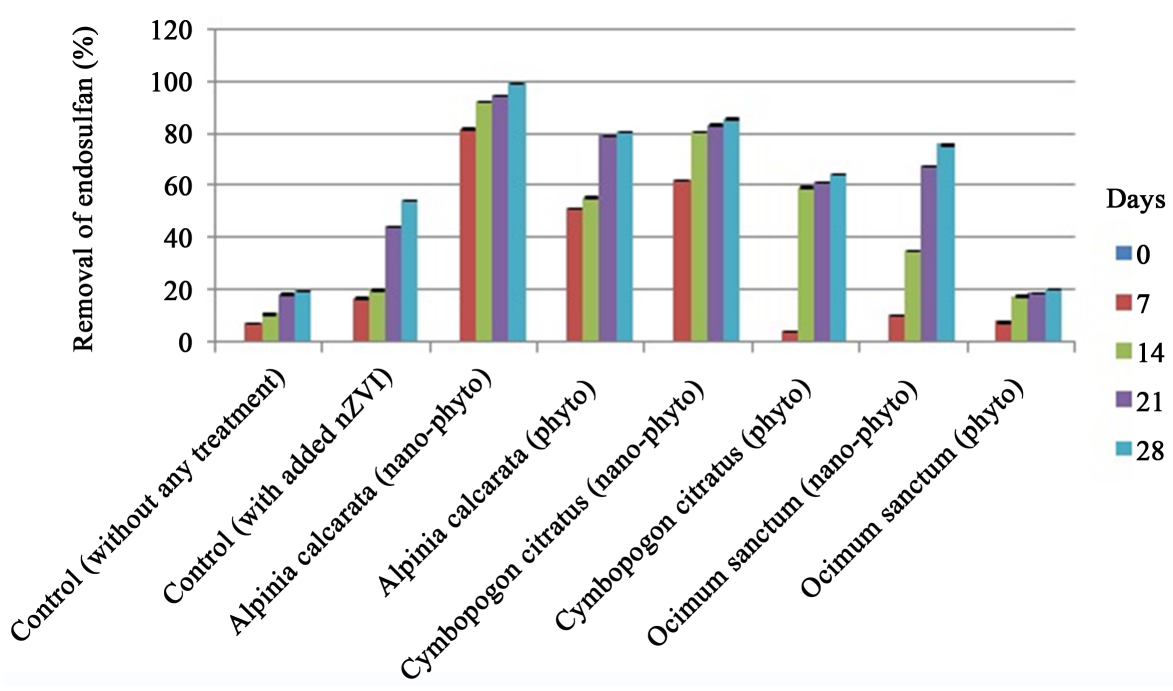

Figure 4. Percentage of the mean concentration of endosulfan in the soil removed in the control, phytoremrediation and nanophytoremediation experiments.

The amount of endosulfan that was degraded naturally in the soil was determined from the results of the control soil samples. Only $20.13 \% \pm 0.33 \%$ of the endosulfan had been removed from the soil in the control experiments within $28 \mathrm{~d}$. About 55\% of the endosulfan was removed from the soil within $28 \mathrm{~d}$ in the control experiments with nZVIs added.

Adding nZVIs to the experiments using plants caused more endosulfan to be removed than was removed by the plants alone. Adding the nZVIs to the soil caused the amount of residual endosulfan in the soil to suddenly decrease. The endosulfan was removed more quickly and effectively in the experiments with A. calcarata and nZVIs than in the experiments with only A. calcarata or only nZVIs, and no endosulfan or its metabolites could be detected in the soil after $28 \mathrm{~d}$. The endosulfan concentration decreased rapidly in the first $7 \mathrm{~d}$ of the experiments with A. calcarata and nZVIs, and the remaining endosulfan was removed more gradually in the following days. The activities of the nZVIs may have gradually decreased because of the Fe (II) being oxidized to form Fe (III). Fe (III) is insoluble and may precipitate and deposit a hydroxide film on the surfaces of nZVIs, decreasing their activities. The formation of hydrogen would also deactivate the reactive sites on nZVIs [25]. The gradual loss of nZVI activity may have caused the gradual decrease in the efficiency at which the endosulfan was removed in our experiments.

The results of analysis of different parts of the plants to determine the accumulated concentration of endosulfan from the soil is given in Table 2. Endosulfan was found in the roots, shoots, and leaves of the plants.

The nZVIs would have reduced the endosulfan in the soil, preventing the normal uptake of the endosulfan by the plants in the nano-phytoremediation experiments [4] [17] [26] [28]. Only 20.35\% of the endosulfan ( $\alpha$-and $\beta$-endosulfan) removed from the soil was found in the A. calcarata tissues, and $12.21 \%$ and $9.84 \%$ of the endosulfan removed from the soil was found in the $O$. sanctum and C. citratus tissues, respectively. In the phyto and nano-phytoremediation experiments using A.calcarata endosulfan was found to be accumulated in higher amounts in the shoot. But in case of other two plant species, higher concentration of endosulfan was found to be accumulated in the root.

The results of the impact of nZVI on the growth of microbial colonies indicated a growth in the number of colonies formed in the soil with added nZVI particles compared to the soil without any added nano particles. Thus the addition of nanoparticles provided a suitable condition for the growth of bacteria [15].

The Fe (0) in nZVIs can become oxidized to form Fe(II) and Fe(III) by reducing organic or inorganic species, and this means that the nZVIs in our experiments can degrade endosulfan effectively in nano-phytoremediation technique. Metallic iron (Fe0) serves effectively as an electron donor [17] [26] as shown in Equation (1).

$$
\mathrm{Fe}^{0} \rightarrow \mathrm{Fe}^{2+}+2 \mathrm{e}^{-}
$$

Some chlorinated pesticides (e.g., endosulfan) can accept electrons and undergo reductive dechlorination [4] [16] [25]. The coupling of the iron oxidation and pesticide reduction reactions is often highly energetically 
Table 2. Presence of endosulfan in plant parts in phytoremediation and nanophytoremediation experiments.

\begin{tabular}{|c|c|c|c|c|c|c|}
\hline Treatment & $\begin{array}{l}\text { Plant } \\
\text { parts }\end{array}$ & $\begin{array}{l}\text { Endosulfan } \\
\text { alpha }(\mu \mathrm{g} / \mathrm{kg})\end{array}$ & $\begin{array}{l}\text { Endosulfan } \\
\text { beta }(\mu \mathrm{g} / \mathrm{kg})\end{array}$ & $\begin{array}{l}\text { Total endosulfan } \\
\text { (alpha + beta) } \\
(\mu \mathrm{g} / \mathrm{kg})\end{array}$ & $\begin{array}{l}\text { Concentration of } \\
\text { Endosulfan inside } \\
\text { the plant }(\mu \mathrm{g} / \mathrm{kg})\end{array}$ & $\begin{array}{l}\text { Percentage } \\
\text { taken up by } \\
\text { the plant (\%) }\end{array}$ \\
\hline \multirow{3}{*}{$\begin{array}{l}\text { Alpinia calcarata } \\
\text { (Phytoremediation) }\end{array}$} & Root & $202.01 \pm 0.59$ & $95.09 \pm 0.93$ & $297.10 \pm 1.27$ & \multirow{3}{*}{916.18} & \multirow{3}{*}{80.38} \\
\hline & Shoot & $314.46 \pm 0.58$ & $171.22 \pm 1.13$ & $485.68 \pm 1.48$ & & \\
\hline & Leaves & $120.51 \pm 0.38$ & $12.89 \pm 0.73$ & $133.40 \pm 0.99$ & & \\
\hline \multirow{3}{*}{$\begin{array}{c}\text { Alpinia calcarata } \\
\text { (Nanophytoremediation) }\end{array}$} & Root & $25.89 \pm 0.80$ & $20.74 \pm 0.16$ & $46.63 \pm 0.69$ & \multirow{3}{*}{231.93} & \multirow{3}{*}{20.35} \\
\hline & Shoot & $152.69 \pm 0.40$ & $32.61 \pm 0.20$ & $185.3 \pm 0.47$ & & \\
\hline & Leaves & BDL & BDL & BDL & & \\
\hline \multirow{3}{*}{$\begin{array}{l}\text { Cymbopogan citrates } \\
\text { (Phytoremediation) }\end{array}$} & Root & $215.41 \pm 0.94$ & $124.13 \pm 1.21$ & $339.54 \pm 1.93$ & \multirow{3}{*}{708.17} & \multirow{3}{*}{62.13} \\
\hline & Shoot & $111.86 \pm 0.66$ & $108.63 \pm 0.45$ & $220.49 \pm 1.02$ & & \\
\hline & Leaves & $80.60 \pm 0.92$ & $67.54 \pm 2.10$ & $148.14 \pm 2.87$ & & \\
\hline \multirow{3}{*}{$\begin{array}{l}\text { Cymbopogan citrates } \\
\text { (Nanophytoremediation) }\end{array}$} & Root & $83.75 \pm 1.64$ & $19.72 \pm 0.41$ & $103.47 \pm 1.25$ & \multirow{3}{*}{112.11} & \multirow{3}{*}{9.84} \\
\hline & Shoot & BDL & BDL & BDL & & \\
\hline & Leaves & $3.04 \pm 0.16$ & $5.60 \pm 0.56$ & $8.64 \pm 0.50$ & & \\
\hline \multirow{3}{*}{$\begin{array}{l}\text { Ocimum sanctum } \\
\text { (Phytoremediation) }\end{array}$} & Root & $15.90 \pm 0.74$ & $144.37 \pm 0.74$ & $160.27 \pm 0.90$ & \multirow{3}{*}{160.27} & \multirow{3}{*}{14.06} \\
\hline & Shoot & BDL & BDL & BDL & & \\
\hline & Leaves & BDL & BDL & BDL & & \\
\hline \multirow{3}{*}{$\begin{array}{c}\text { Ocimum sanctum } \\
\text { (Nanophytoremediation) }\end{array}$} & Root & $11.48 \pm 0.99$ & $127.70 \pm 1.99$ & $139.18 \pm 1.75$ & \multirow{3}{*}{139.18} & \multirow{3}{*}{12.21} \\
\hline & Shoot & BDL & BDL & BDL & & \\
\hline & Leaves & BDL & BDL & BDL & & \\
\hline
\end{tabular}

BDL: Below detection limit; Detection limit: $0.05 \mu \mathrm{g} / \mathrm{kg}$; Initial concentration of endosulfan applied to the soil: $1139.84 \pm 0.93 \mu \mathrm{g} / \mathrm{kg}$.

favorable from a thermodynamic perspective [26]-[28]. The degradation of endosulfan by nZVIs involves hydrogenolysis through sequential dehalogenation. The presence of plants would have accelerated the removal of endosulfan from the soil by effectively phytoextracting it. The endosulfan isomers were detected to be less in plants involved in nano-phytoremediation than in simple phytoremediation experiments. This clearly indicates that the nZVIs played an important role in the endosulfan detoxification process in the nano-phytoremediation experiments. The dechlorination product of endosulfan was found to be Bicyclo [2] [21] hepta 2-5 diene from GC-MS analysis which is in line with the observations of Aginhotri et al. [28] and Begum et al. [29]. GC -MS analysis did not indicate the presence of any partially chlorinated intermediates.

Statistical summary (ANOVA) to find out the influence of days and treatments on endosulfan concentration are presented in Table 3.

It could be seen from the Table 3 that there is significant difference between treatments in the total endosulfan concentrations $(p<0.001)$. Using the least significant difference (LSD) noteworthy treatment effects was identified. Significantly higher endosulfan concentrations were observed in control and Ocimum Sanctum (phytoremediation).Significantly lower concentrations of endosulfan were noted in Alpinia calcarata (nano phytoremediation), Cymbopogon citrates (phytoremediation) and Alpinia calcarata (phytoremediation).

It can be inferred from Table 3 that, there is significant difference between days with respect to total endosulfan concentrations ( $p<0.001)$. "0" day endosulfan concentration is significantly higher than all the rest ( $p<$ 0.001). Endosulfan concentration is significantly low after 14, 21 and 28 days; the difference in their mean values are not significant.

Table 4 gives the ANOVA of percentage of endosulfan removal. There is significant difference between treatments in the removal of percentage endosulfan $(p<0.001)$. Alpinia calcarata (nano phytoremediation) 
Table 3. Two-way ANOVA analysis results for the influence of days and treatments on the concentration of endosulfan in soil.

\begin{tabular}{cccc}
\hline Sl. No. & Factors & Variance Ratio $(\mathrm{F})$ & Level of significance $(p$-value $)$ \\
\hline 1 & Days & 17.663 & $p<0.001$ \\
2 & Treatments & 10.192 & $p<0.001$ \\
\hline
\end{tabular}

Table 4. Two-way ANOVA analysis results for the influence of days and treatments on the percentage of endosulfan removal from soil.

\begin{tabular}{cccc}
\hline Sl. No. & Factors & Variance Ratio $(\mathrm{F})$ & Level of significance $(p$-value $)$ \\
\hline 1 & Days & 10.634 & $p<0.001$ \\
2 & Treatments & 26.321 & $p<0.001$ \\
\hline
\end{tabular}

followed by Cymbopogon citrates (nano phytoremediation) have removed significantly higher percentage of endosulfan. Significantly lower percentage of removal of endosulfan was observed in the control and Ocimum sanctum (phytoremediation).

Percentage removal of endosulfan between days also depicted a significant difference $(p<0.001)$.The percentage removal of endosulan is significantly higher after 28 days, followed by that in 21 days.

\section{Conclusion}

The possibility of combining nano-remediation and phytoremediation to remediate soil contaminated with endosulfan was assessed in this study. The outcome of the study can be very useful for the application in field since the advantages of phytoremediation and nanoremediation are combined in this technology. The unique properties and high surface areas of nZVIs can improve on many of the advantages offered by traditional iron remediation techniques. Considering the current and future impacts of chlorinated organic pesticides like endosulfan on the environment and human health, the successful implementation of this low-cost technology could be highly beneficial to the society. We found that endosulfan was rapidly and efficiently removed from contaminated soil using a nano-phytoremediation method. The terrestrial plant $A$. calcarata and nZVIs accelerated the removal of endosulfan from the contaminated soil within one month. It appears that the process involves the reductive dechlorination of endosulfan by the nZVIs and the enzymatic metabolism of endosulfan in the plants. For remediation application, nanoparticles were pumped directly into the soil along with surfactant solution. Hence the treatment method will minimise the impact of nanoparticles interacting with gases and other airborne particles.

\section{Acknowledgements}

K. Jesitha gratefully acknowledges financial support from the "Back to Lab Programme" of the Women Scientists Division of Kerala State Council for Science Technology and Environment, Thiruvananthapuram, Kerala, India.

\section{References}

[1] Bootharaju, M.S. and Pradeep, T. (2012) Understanding the Degradation Pathway of the Pesticide, Chlorpyrifos by Noble Metal Nanoparticles. Langmuir, 28, 2671-2679. http://dx.doi.org/10.1021/la2050515

[2] Adeleye, A.S., Keller, A.A., Miller, R.J. and Lenihan, H.S. (2013) Persistence of Commercial Nanoscaled Zero-Valent Iron (nZVI) and By-Products. Journal of Nanoparticle Research, 15, 1401-1418. http://dx.doi.org/10.1007/s11051-013-1418-7

[3] Dayan, H., Abrajano, T., Sturchio, N.C. and Winsor, L. (1999) Carbon Isotopic Fractionation during Reductive Dehalogenation of Chlorinated Ethenes by Metallic Iron. Organic Geochemistry, 30, 755-763. http://dx.doi.org/10.1016/S0146-6380(99)00058-3

[4] Muller, N.C. and Nowack, B. (2010) Nano Zero Valent Iron-The Solution for Water and Soil Remediation. Observatory NANO Focus Report, Netherlands. 
[5] Nair, A.S., Tom, R.T. and Pradeep, T. (2003) Detection and Extraction of Endosulfan by Metal Nanoparticles. Journal of Environmental Monitoring, 5, 363-365. http://dx.doi.org/10.1039/b300107e

[6] Campos, V.M., Merino, I., Casado, R., Pacios, L.F. and Gomez, L. (2008) Phytoremediation of Organic Pollutants. Spanish Journal of Agricultural Research, 6, 38-47. http://dx.doi.org/10.5424/sjar/200806S1-372

[7] Frazar, C. (2000) The Bioremediation and Phytoremediation of Pesticide Contaminated Sites. National Service Center for Environmental Publications NSCEP). Prepared for US Environmental Protection Agency, Washington DC. http://www.clu-in.org

[8] Cardeal, Z.L., Souza, A.G. and Amorim, L.C.A. (2011) Analytical Methods for Performing Pesticide Degradation Studies in Environmental Sample. InTech Publishers, New York.

[9] Leung, A.M., McDonough, D.M. and West, C.D. (1998). Determination of Endosulfan in Soil/Sediment Samples from Point Mogu, Oxnard, CA Using Capillary Gas Chromatography/ Mass Selective Detection (GC/MSD). Environmental Monitoring and Assessment, 50, 85-94. http://dx.doi.org/10.1023/A:1005737814714

[10] Rao, D.M.R. and Murthy, A.S. (1980) Persistence of Endosulfan in Soils. Journal of Agricultural and Food Chemistry, 28, 1099-1101. http://dx.doi.org/10.1021/jf60232a012

[11] United States Environmental Protection Agency (2002) Reregistration Eligibility Decision for Endosulfan. United States Environmental Protection Agency, Washington DC.

[12] Harikumar, P.S., Jesitha, K., Megha, T. and Kokkal, K. (2014) Persistence of Endosulfan in Selected Areas of Kasaragod District, Kerala. Current Science, 106, 1421-1429.

[13] Li, X., Elliott, D.W. and Zhang, W. (2006) Zero-Valent Iron Nanoparticles for Abatement of Environmental Pollutants: Materials and Engineering Aspects. Critical Reviews in Solid State and Material Sciences, 31, 111-122. http://dx.doi.org/10.1080/10408430601057611

[14] Cook, S.M. (2009) Assessing the Use and Application of Zero-Valent Iron Nanoparticle Technology for Remediation at Contaminated Sites. Prepared for U.S. Environmental Protection Agency, Office of Solid Waste and Emergency Response, Office of Superfund Remediation and Technology Innovation, Washington DC.

[15] Shi, Z., Fan, B., Johnson, R.L., Tratnyek, P.G., Nurmi, J.T., Wu, Y. and Williams, K.H. (2015) Methods for Characterizing the Fate and Effects of Nano Zerovalent Iron during Groundwater Remediation. Journal of Contaminant Hydrology, 181, 17-35. http://dx.doi.org/10.1016/j.jconhyd.2015.03.004

[16] Manilal, K.S. (2003) Hortus Malabaricus (Malayalam). University of Kerala, Thiruvananthapuram.

[17] Poursaberi, T., Konoz, E., Mohsen Sarrafi, A.H., Hassanisadi, M. and Hajifathli, F. (2012) Application of Nanoscale Zero-Valent Iron in the Remediation of DDT from Contaminated Water. Chemical Science Transactions, 1, 658-668. http://dx.doi.org/10.7598/cst2012.246

[18] Rahmani, A.R., Ghaffari, H.R. and Samadi, M.T. (2011) A Comparative Study on Arsenic (iii) Removal from Aqueous Solution using Nano and Micro Sized Zero-Valent Iron. Iranian Journal of Environmental Health Science and Engineering, 8, 157-166.

[19] Madhavi, V., Prasad, T.N.V.K.V. and Madhavi, G. (2013) Synthesis and Spectral Characterization of Iron Based Micro and Nanoparticles. International Journal of Nanomaterials and Biostructures, 3, 31-34. http://dx.doi.org/10.5829/idosi.ijee.2013.04.04.10

[20] American Public Health Association (2012) Standard Methods for the Examination of Water and Wastewater. 22nd Edition, American Public Health Association, Washington DC.

[21] Harikumar, P.S., Jesitha, K. and Sreechithra, M. (2013). Remediation of Endosulfan by Biotic and Abiotic Methods. Journal of Environmental Protection, 4, 418-425. http://dx.doi.org/10.4236/jep.2013.45050

[22] United States Environmental Protection Agency (1984) Methods for Organic Chemical Analysis of Municipal and Industrial Waste Water. National Technical Information Service, Springfield.

[23] Sun, Y.P., Li, X., Cao, J., Zhang, W. and Wang, H.P. (2006) Characterization of Zero-Valent Iron Nanoparticles. Advances in Colloid and Interface Science, 120, 47-56. http://dx.doi.org/10.1016/j.cis.2006.03.001

[24] Jiamjitrpanich, W., Parkpian, P., Polprasert, C. and Kosanlavit, R. (2013) Trinitrotoluene and Its Metabolites in Shoots and Roots of Panicum Maximum in Nano-Phytoremediation. International Journal of Environmental Science and Development, 4, 7-10. http://dx.doi.org/10.7763/IJESD.2013.V4.293

[25] Vodyanitskii, N., Mineev, V.G. and Shoba, S.A. (2014) Role of Zero-Valent Iron in the Degradation of Organochlorine Substances in Ground Water, Moscow University. Soil Sciences Bulletin, 69, 175-183.

[26] Yan, W., Lien, H.L., Koelc, B.E. and Zhang, W. (2013) Iron Nanoparticles for Environmental Clean-Up: Recent Developments and Future Outlook. Environmental Science: Processes and Impacts, 15, 63-77.

http://dx.doi.org/10.1039/c2em30691c 
[27] Agarwal, A. and Joshi, H. (2010) Application of Nanotechnology in the Remediation of Contaminated Groundwater: A Short Review. Recent Research in Science and Technology, 2, 51-57.

[28] Aginhotri, P., Mahidrakar, A.B. and Gautam, S.K. (2011) Complete Dechlorination of Endosulfan and Lindane Using $\mathrm{Mg}^{0} / \mathrm{Pd}^{+4}$ Bimetallic System. Water Environment Research, 83, 865-873. http://dx.doi.org/10.2175/106143011X12928814445096

[29] Begum, A., Agnihotri, P., Mahindrakar, A.B. and Gautam, S.K. (2014) Degradation of Endosulfan and Lindane Using Fenton's Reagent. Applied Water Science, 10, 1-9. http://dx.doi.org/10.1007/s13201-014-0237-z 